\title{
Two cases of human cutaneous anthrax in Bosnia and Herzegovina, September 2014
}

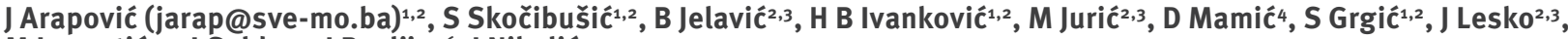

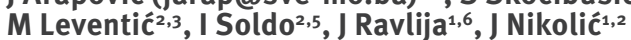

1. Department of Infectious Diseases, University Hospital Mostar, Mostar, Bosnia and Herzegovina

2. School of Medicine, University of Mostar, Mostar, Bosnia and Herzegovina

3. Department of Otorhinolaryngology and Maxillofacial Surgery, University Hospital Mostar, Mostar, Bosnia and Herzegovina

4. Department of Epidemiology and Public Health, Public Health Institute of Livno, Livno, Bosnia and Herzegovina

5. Department of Radiology, University Hospital Mostar, Mostar, Bosnia and Herzegovina

6. Department of Epidemiology, Public Health Institute of Federation of Bosnia and Herzegovina, Sarajevo, Bosnia and Herzegovina

Arapović J, Skočibušić S, Jelavić B, Ivanković HB, Jurić M, Mamić D, Grgić S, Lesko J, Leventić M, Soldo I, Ravlija J, Nikolić J. Two cases of human cutaneous anthrax in Bosnia and Herzegovina, September 2014. Euro Surveill. 2015;20(7):pii=21039. Available online: http://www.eurosurveillance.org/ViewArticle. aspx?Articleld $=21039$

Article submitted on 25 January 2015 / published on 19 February 2015

Two cases of human cutaneous anthrax were reported in September 2014 in south-western Bosnia and Herzegovina. The two men were involved in slaughtering a cow and handled its Bacillus anthracis-infected meat. Anthrax has been sporadically observed in livestock in Bosnia and Herzegovina, but no confirmed human cases had been reported in the country in the last two decades. Clinicians in the country should be aware that anthrax may occur in humans, arising from exposure to infected animals.

\section{Case report}

Two men from a rural community in south-western Bosnia and Herzegovina presented with cutaneous anthrax in September 2014 after slaughtering a cow and handling its meat, which was later found to be infected by Bacillus anthracis, the causative agent of anthrax.

\section{Case 1}

The man, in his early thirties, had been involved in the cow's slaughter and handling of its meat at the end of August 2014. During the meat handling, his right infraorbital region was struck by a bone of the cow, which resulted in a small superficial skin lesion and crusting. Due to swelling and redness of the right orbital and infraorbital region, he was examined by an otorhinolaryngologist and ophthalmologist at the regional general hospital. Despite being prescribed oral azithromycin $500 \mathrm{mg}$ daily and corticosteroids, there was a progression of periorbital cellulitis and he was admitted to the same hospital in early September 2014. His treatment included azithromycin, local antibiotic and corticosteroid therapy for his eye and antihistamines. The day following admission, due to suspicion of rhinosinusitis complications, he was admitted to the Department of Otorhinolaryngology and Maxillofacial Surgery at the University Hospital in Mostar. He felt no pain in his right eye and had no fever. Serum concentration of C-reactive protein (CRP) was increased $(68.3$ $\mathrm{mg} / \mathrm{L}$; norm: $0-5 \mathrm{mg} / \mathrm{L}$ ), while the erythrocyte sedimentation rate, and levels of leukocytes, erythrocytes, haemoglobin, platelets, liver transaminases were all within the normal ranges. The results of urine analysis were also normal. Computed tomography scans showed healthy maxillary and ethmoid sinuses, and diffuse soft tissue oedema of the right-hand side of his face.

In the following days, due to the extent and spread of the swelling to the left orbital region, the patient reported intense pain. In order to decrease skin tension and facial pain, an incision in the right upper buccal vestibule was made and the pain was relieved successfully. Swab cultures of the wound and right eye tested negative for the presence of aerobic bacteria. However, a characteristic malignant pustule (dark crust) appeared in the affected infraorbital region.

Given the presence of the pustule, cutaneous anthrax was suspected and the patient was admitted to the Department of Infectious Diseases at the University Hospital in Mostar, and the local Department of Epidemiology and Public Health was informed about the case. Epidemiological investigation and analysis of frozen meat from the cow (by bacteriological cultivation) confirmed the presence of $B$. anthracis on 21 September 2014 .

The patient was initially treated with an empirically combined antimicrobial therapy (ceftriaxone, $2 \mathrm{~g}$ once daily, and metronidazole, $500 \mathrm{mg}$ three times daily, intravenously) for periorbital and facial cellulitis. While still in the Department of Infectious Diseases, the antimicrobial therapy was modified, with administration of penicillin G, 4 million international units (IU) four times 
intravenously daily for the next 10 days. The patient also received local ophthalmic antimicrobial therapy (tobramycin solution). Clinical recovery was followed by regression of local swelling and peeling of the dark crust and normalisation of CRP levels.

\section{Case 2}

A man in his early fifties, a relative of Case 1 , who had also been involved in slaughtering the same cow and handling its meat, presented to a primary care practice in September 2014 with a wound on the volar side of his right forearm. The wound was about $3 \mathrm{~cm}$ in diameter and covered with a black crust. The area was slightly oedematous. At the regional general hospital, he was diagnosed as having allergic contact dermatitis and was initially treated with corticosteroids, then with amoxicillin/clavulanate potassium $(800 / 200 \mathrm{mg})$ orally two times daily for seven days, and finally with corticosteroids and cefuroxime axetil $500 \mathrm{mg}$ orally two times daily. As there had been no clinical improvement, and as it was known he had also been involved in the slaughter of the infected cow, he was admitted to the Department of Infectious Diseases, University Hospital in Mostar, towards the end of September 2014, shortly after $B$. anthracis had been detected in the cow's meat. Cutaneous anthrax was suspected, given his symptoms and following an epidemiological investigation. He was successfully treated with ciprofloxacin $500 \mathrm{mg}$ orally two times daily for 14 days.

\section{Background}

B. anthracis is a sporulating Gram-positive bacterium. The main routes of human exposure to spores are by inhalation, ingestion, contact with skin and injection of contaminated drugs $[1,2]$. In most patients (95\%), the disease manifests as cutaneous anthrax, whereas the remaining $5 \%$ of cases present with inhalational or gastrointestinal syndromes [3]. Of these two forms, the most severe is inhalational anthrax, which is usually fatal if left untreated. In such cases, often acts of bioterrorism are suspected [1-4]. Cutaneous anthrax on the other hand generally develops after direct contact with infected animals or animal products. Symptoms typically appear up to 17 days after contact [5], but in an experimental model, the incubation time can be up to 58 days [6]. Thus, cases of cutaneous anthrax are reported as an occupational disease, which mostly occurs in farmers, butchers, dealers of hides and animal hair, wool sorters and veterinarians [4]. Characteristic of cutaneous anthrax is the appearance of a malignant pustule surrounded by oedema at the infection site [7]. Due to the use of antibiotics, the mortality rate is typically under $1 \%$, but if left untreated the fatality rate can reach $20 \%[2,7]$.

Anthrax has been used in bioterrorism. The only documented terrorist attack with anthrax spores was in 1993 by the Aum Shinrikyo cult in Japan; there were no cases [8]. During deliberate release of weaponised anthrax spores in 2001 in the United States, 28 people tested positive for $B$. anthracis in nasal swabs, 22 became ill and five people died $[1,6]$.

Sporadic anthrax in livestock was last reported in Bosnia and Herzegovina in 2010 [9-11], but no confirmed cases of cutaneous anthrax in humans had been reported in this country in the last two decades. In 2011, sporadic human cutaneous anthrax cases due to contact with infected livestock were reported in Serbia [12], which borders with Bosnia and Herzegovina, and in Romania [13]. Sporadic livestock anthrax cases have also been reported in the past 25 years in areas of Croatia bordering Bosnia and Herzegovina $[9,14,15]$.

The two cases reported here should be considered as an alert to the medical community in Bosnia and Herzegovina to the possible appearance of anthrax in humans arising from exposure to infected animals.

\section{Discussion}

The last reported case of anthrax in humans in Bosnia and Herzegovina was in 1992, a woman from the rural south-western part of the country, who was hospitalised and treated for cutaneous anthrax in Split, Croatia [16]. A possible human anthrax case in Bosnia and Herzegovina - a person from neighbouring Serbia - was reported in 2009 in Bosnia and Herzegovina's epidemiological bulletin [17], but the infection was not confirmed by laboratory analysis or epidemiological investigation (unpublished data).

Floods in Bosnia and Herzegovina and neighbouring countries in May 2014 could wash and mobilise $B$. anthracis spores from deeper layers in the soil. In addition to classical infection by contact with bacteria or spores, $B$. anthracis might also be transmitted by insects $[16,18]$, which are especially active in warmer (summer) days, although the epidemiological impact of biting and/or non-biting insects in anthrax infection is not yet fully understood.

The structure of the epidemiological and veterinary services in Bosnia and Herzegovina should also be borne in mind regarding anthrax control. One of the two political entities in the country is the Federation of Bosnia and Herzegovina, which is divided into 10 independently structured counties. Every county has its own department of public health and veterinary department, leading to challenging control, coordination and prevention of infectious diseases through appropriate vaccination of livestock.

As described by Kracalik et al. for Georgia [19,20], vaccination of livestock and education of cattle workers could be the basis of an effective strategy for the prevention of anthrax also in Bosnia and Herzegovina and thus for the avoidance of anthrax spread. Thus, a longterm vaccination programme in livestock coordinated by the government would be helpful as an important measure to prevent the spread of anthrax in Bosnia and Herzegovina. 
The human cases reported here should serve as a reminder to healthcare personnel in Bosnia and Herzegovina to be vigilant.

\section{Acknowledgements}

The authors are grateful to all doctors and nurses at the University Hospital Mostar who helped in the handling and treatment of the cutaneous anthrax patients. Also, we thank Dr Maja Arapović and Dr Luka Traven for critical reading of the manuscript.

\section{Conflicts of interest}

None declared.

\section{Authors' contributions}

JA coordinated all correspondence, designed and wrote the first version of the manuscript. SS and BJ contributed to the conception and writing of the first version of manuscript. JA, SS, JN, HBI, SG, MJ, BJ, JL, IS, JR and ML contributed to clinical analysis. $\mathrm{HBI}$ contributed to the data interpretation and handled patients' approval for publication of personal data. $J \mathrm{~L}, \mathrm{BJ}$ and IS contributed in performing clinical data and interpretation of data. JR, JN and DM conducted all epidemiological measures on the spot of the anthrax outbreak. DM provided the analysis of anthrax. All authors contributed in the writing of the final version of manuscript.
12. Durić P, Cosić G, Rajčević S, Petrovic V, Tomković M, Subić Z, et al. Three probable cases of cutaneous anthrax in autonomous province of Vojvodina, Serbia, June 2011. Euro Surveill. 2012;17(1). pii: 20050. 20050. PMID: 22264812

13. Popescu R, Pistol A, Miltaru L, Caplan D, Cucuiu R, Popovici F. Two cases of infection with Bacillus anthracis, Romania, October 2011. Euro Surveill. 2011;16(45). pii: 20008. PMID: 22114977

14. Markotić A, Krajinović LC, Margaletić J, Turk N, Miletić-Medved $M, Z$ mak L, et al. Zoonoses and vector-borne diseases in Croatia - a multidisciplinary approach. Vet Ital. 2009;45(1):5566. PMID:20391390

15. Habrun B, Račić I, Kompes G, Spičić S, Benić M, Mihaljević Z, et al. The antimicrobial susceptibility and virulence factors of Bacillus anthracis strains isolated in Croatia. Vet Med (Praha). 2011;56(1):22-7. http://vri.cz/docs/vetmed/56-1-22.pdf

16. Bradarić N, Punda-Polić V. Cutaneous anthrax due to penicillinresistant Bacillus anthracis transmitted by an insect bite. Lancet. 1992;340(8814):306-7. http://dx.doi.org/10.1016/01406736(92)92395-V PMID:1353216

17. Epidemiološka situacija na području Federacije Bosne i Hercegovine U 2010. [The epidemiological situation in the Federation of Bosnia and Herzegovina in 2010]. Epidemiological bulletin 18(29). Sarajevo/Mostar: Institute of Public Health FB\&H; 2011. Croatian. p. 22,34-5. Available from: http://www.zzjzfbih.ba/wp-content/uploads/2010/02/ Epidemioloski-bilten-29-god-2010.pdf

18. Bradarić N, Vilić N. (Epidemiologic and clinical characteristics of anthrax in patients at the University Hospital in Split 19561987]. Lijec Vjesn. 1992;114(5-8):122-6. Croatian. PMID:1343041

19. Kracalik I, Malania L, Tsertsvadze N, Manvelyan J, Bakanidze L, Imnadze P, et al. Human cutaneous anthrax, Georgia 2010-2012. Emerg Infect Dis. 2014;20(2):261-4. http://dx.doi. org/10.3201/eid2002.130522 PMID:24447721

20. Kracalik IT, Malania L, Tsertsvadze N, Manvelyan J, Bakanidze L, Imnadze P, et al. Evidence of local persistence of human anthrax in the country of Georgia associated with environmental and anthropogenic factors. PLoS Negl Trop Dis. 2013;7(9):e2388. http://dx.doi.org/10.1371/journal. pntd.0002388 PMID:24040426

\section{References}

1. Swartz MN. Recognition and management of anthrax--an update. N Engl J Med. 2001;345(22):1621-6. http://dx.doi. org/10.1056/NEJMra012892 PMID:11704686

2. Sweeney DA, Hicks CW, Cui X, Li Y, Eichacker PQ. Anthrax infection. Am J Respir Crit Care Med. 2011;184(12):1333-41. http://dx.doi.org/10.1164/rccm.201102-0209CI PMID:21852539

3. Dixon TC, Meselson M, Guillemin J, Hanna PC. Anthrax. N Engl J Med. 1999;341(11):815-26. http://dx.doi.org/10.1056/ NEJM199909093411107 PMID:10477781

4. Schmid G, Kaufmann A. Anthrax in Europe: its epidemiology, clinical characteristics, and role in bioterrorism. Clin Microbiol Infect. 2002;8(8):479-88. http://dx.doi. org/10.1046/j.1469-0691.2002.00500.x

5. Doganay M, Metan G, Alp E. A review of cutaneous anthrax and its outcome. J Infect Public Health. 2010;3(3):98-105. http:// dx.doi.org/10.1016/j.jiph.2010.07.004 PMID:20869669

6. Wright JG, Quinn CP, Shadomy S, Messonnier N; Centers for Disease Control and Prevention (CDC). Use of anthrax vaccine in the United States: recommendations of the Advisory Committee on Immunization Practices (ACIP), 2009. MMWR Recomm Rep. 2010;59(RR-6):1-30. PMID: 20651644

7. Wenner KA, Kenner JR. Anthrax. Dermatol Clin. 2004;22(3):247 56, v. http://dx.doi.org/10.1016/j.det.2004.03.001 PMID: 15207306

8. Keim P, Smith KL, Keys C, Takahashi H, Kurata T, Kaufmann A. Molecular investigation of the Aum Shinrikyo anthrax release in Kameido, Japan. J Clin Microbiol. 2001;39(12):4566-7.

9. Steiner I, Račić I, Spičić S, Habrun B. Genotyping of Bacillus anthracis isolated from Croatia and Bosnia and Herzegovina. Zoonoses Public Health. 2013;60(3):202-8. http://dx.doi. org/10.1111/j.1863-2378.2012.01513.x PMID:22726272

10. Hukic M, Numanovic F, Sisirak M, Moro A, Dervovic E, Jakovec $S$, et al. Surveillance of wildlife zoonotic diseases in the Balkans Region. Med Glas (Zenica). 2010;7(2):96-105.

11. FluTrackers.com. Bosnia and Herzegovina - Again anthrax confirmed in cows. Winter Park, FL: FluTrackers.com, Inc. Posted 26 Aug 2010. [Acccessed 12 Feb 2015]. Available from: https://flutrackers.com/forum/forum/emerging-diseasesother-health-threats-alphabetical-a-thru-h/anthrax-aa/92288bosnia-and-herzegovina-again-anthrax-confirmed-in-cows 